\title{
PENGARUH BUDAYA ORGANISASI TERHADAP KINERJA GURU DI SMK NEGERI 2 NGAWI TAHUN 2014
}

\author{
Anna Tri Yuliastuti Wulandari \\ Mahasisiwa Prodi Pendidikan Ekonomi IKIP PGRI Madiun \\ anna_muslimah1234@yahoo.com
}

\begin{abstract}
This research have a purpose to know organizational culture in SMK Neger 2 Ngawi Year 2014, to know performance learn SMK Country 2 Ngawi Year 2014 and to know is there any cultural influence of organization to performance learn SMK Country 2 Ngawi Year 2014. Determination of sampel in this research use saturated sampel that is all teacher in SMK Country 2 Ngawi Year 2014 amounting to 40 teacher. Data collecting use or enquette of kuisioner. In analysing data use statistical aid method and use linear analysis modestly to test hypothesis which is told in research. Pursuant to result of research obtained by the level of value of $r_{\text {hitung }}$ is 0,834 and $r_{\text {tabel }} 0,312$, on the other hand the level of $\operatorname{Sig}_{\text {hitung }} 0,000$. and $\operatorname{Sig}_{\text {prob }}$ 0,05. Matter this means that value of $r_{\text {hitung }} \geq r_{\text {tabel }}$ ( $0,834 \geq 0,312)$ or Sighitung $\leq$ Sigprob $(0,000 \leq 0,05)$. On the basis of correlation test, test $\mathrm{F}$ and test of $\mathrm{t}$ can be concluded that there is influence among/between Organizational Culture to Performance Learn In SMK Country 2 Ngawi Year 2014.
\end{abstract}

Key words: Cultural of Organization, Performance Teacher

\begin{abstract}
Abstrak. Penelitian ini mempunyai tujuan untuk mengetahui budaya organisasi di SMK Neger 2 Ngawi Tahun 2014, untuk mengetahui kinerja guru SMK Negeri 2 Ngawi Tahun 2014 dan untuk mengetahui adakah pengaruh budaya organisasi terhadap kinerja guru SMK Negeri 2 Ngawi Tahun 2014. Penentuan sampel dalam penelitian ini menggunakan sampel jenuh yaitu semua guru di SMK Negeri 2 Ngawi Tahun 2014 yang berjumlah 40 guru. Pengumpulan data menggunakan angket atau kuisioner. Dalam menganalisis data menggunakan metode bantuan statistik dan menggunakan analisis linier sederhana untuk menguji hipotesis yang dikemukakan dalam penelitian. Berdasarkan hasil penelitian diperoleh besarnya nilai $r_{\text {hitung }}$ adalah 0,834 dan $r_{\text {tabel }} 0,312$, dilain pihak besarnya Sig gitung 0,000. dan $\operatorname{Sig}_{\text {prob }} 0,05$. Hal ini berarti bahwa nilai $r_{\text {hitung }} \geq r_{\text {tabel }}(0,834 \geq 0,312)$ atau $\operatorname{Sig}_{\text {hitung }}$ $\leq \operatorname{Sig}_{\text {prob }}(0,000 \leq 0,05)$. Atas dasar uji korelasi, uji $\mathrm{F}$ dan uji t dapat disimpulkan bahwa ada pengaruh antara Budaya Organisasi terhadap Kinerja Guru Di SMK Negeri 2 Ngawi Tahun 2014.
\end{abstract}

Kata Kunci: Budaya Organisasi, Kinerja Guru

\section{PENDAHULUAN}

Pendidikan merupakan

kebutuhan yang penting untuk

dipenuhi sama pentingnya seperti

pemenuhan kebutuhan pangan, sandang, papan. Pendidikan diperlukan oleh manusia sejak usia dini sampai usia lanjut. Jika pendidikan mengalami hambatan dapat mengakibatkan tidak 
maksimalnya perkembangan belajar di masa depan.

Menurut Robins dan judgle (dalam Danang Sunyoto, 2012: 225) Budaya organisasi adalah sebuah sistem makna bersama yang dianut oleh para anggota organisasi yang membedakan organisasi tersebut dengan organisasi yang lain. Sedangkan menurut Edy Sutrisno (2011: 2) Budaya organisasi merupakan suatu kekuatan sosial yang tidak tampak, yang dapat menggerakkan orang-orang dalam suatu organisasi untuk melakukan aktivitas kerja. Secara tidak langsung setiap orang mempelajari budaya dalam suatu organisasinya. Apalagi bila dia sebagai seorang guru baru agar dapat diterima oleh lingkungan dimana guru tersebut bekerja, harus berusaha mempelajari apa yang dilarang dan apa yang diwajibkan, apa yang baik dan apa yang buruk, apa yang benar dan apa yang salah sehingga guru tersebut harus melakukan apa yang dilakukan dan apa yang tidak boleh dilakukan di dalam organisasi.

Menurut Moeheriono (2009: 60) kinerja atau performance merupakan gambaran mengenai tingkat pencapaian pelaksanaan suatu program kegiatan atau kebijakan dalam mewujudkan sasaran, tujuan, visi dan misi organisasi yang dituangkan melalui perencanaan strategis suatu organisasi. Kinerja guru dapat diketahui dan diukur jika individu telah mempunyai kreteria atau standar keberhasilan tolok ukur yang ditetapkan organisasi. Oleh sebab itu jika tanpa tujuan dan target yang ditetapkan dalam pengukuran, maka kinerja pada seseorang atau kinerja organisasi tidak mungkin dapat diketahui bila tidak ada tolok ukur keberhasilannya.

Masyarakat mengharapkan kinerja guru dapat berprestasi dan mampu menciptakan situasi dan kondisi yang kondusif sehingga guru tidak mengalami kejenuhan, kebosanan dan malas bekerja sehingga mengalami penurunan kinerja. Keberhasilan kinerja guru hal yang paling utama dalam mendidik anak didik adalah menghasilkan anak didik yang berkualitas tinggi.

Dalam meningkatkan kinerja guru yang baik seorang guru harus meningkatkan sumber daya manusia agar tercapai tujuan dalam mendidik anak didik. Dengan adanya dukungan dari sumber daya manusia dan teknologi di sekolah maka guru dapat melaksanakan tugasnya dalam mendidik anak didiknya.

Untuk mencapai hasil dalam mendidik anak tidak hanya kinerja guru saja yang diperlukan tetapi budaya organisasi juga sangat diperlukan dalam mendidik anak didik yang mempunyai kualitas yang tinggi. Maka dari itu disekolah diperlukan budaya organisasi untuk memajukan anak didik yang berkualitas tinggi. SMK Negeri 2 Ngawi berdiri pada pertengahan 2004 dengan nama SMKN 3 Ngawi. Sekolah menengah kejuruan negeri 3 Ngawi pada awal pendirian belum mempunyai gedung sendiri tetapi masing menumpang di SMKN 1 Ngawi. Awal tahun 2005 SMKN 3 Ngawi sudah mempunyai gedung sendiri meskipun baru 6 lokal. Tahun 2007 SMKN 3 Ngawi berubah nama menjadi SMKN 2 Ngawi sampai sekarang. SMKN 2 Ngawi mempunyai jurusan yang meliputi 
teknik Gambar dan bangunan, teknik kendaraan ringan, kecantikan rambut, busana butik dan akuntansi. Guru SMKN 2 Ngawi memahami tugas dan tanggung jawab yang amat berat tetapi mulia dan siap membantu anak didik yang mengalami kesulitan ketika melakukan kegiatan maupun belajar.

Dengan adanya budaya organisasi dan kinerja guru di sekolah maka guru yang bekerja disekolah SMKN 2 Ngawi dapat bekerja sama dengan baik sehingga menghasilan anak didik yang mempunyai kualitas tinggi. Secara tidak langsung mereka mempunyai keinginan untuk memajukan anak didiknya, Walaupun dalam mendidik anak tidak mudah tetapi mereka mempunyai semangat yang tinggi. Melalui budaya organisasi kinerja guru yang kuat dapat menghasilkan kualitas guru yang baik dan tercapainya tujuan yang ada disekolah. Kualitas budaya organisasi dan kinerja guru dapat dilihat dari kerja sama antara guru satu dengan guru yang lain.

Berdasarkan latar belakang masalah dapat dirumuskan pernyataan permasalahan sebagai berikut : pertama, Bagaimana budaya organisasi di SMKN 2 Ngawi tahun 2014?, kedua, Bagaimana kinerja guru di SMKN 2 Ngawi tahun 2014? Ketiga, Adakah Pengaruh budaya organisasi terhadap kinerja guru di SMKN 2 Ngawi tahun 2014?

Ada tiga Tujuan yang hendak dicapai dalam penelitian ini yaitu: pertama, Untuk mengetahui budaya organisasi di SMKN 2 Ngawi tahun 2014, kedua, Untuk mengetahui kinerja guru di SMKN 2 Ngawi tahun 2014 dan ketiga, Untuk mengetahui adakah pengaruh budaya organisasi terhadap kinerja guru di SMKN 2 Ngawi tahun 2014.

Menurut Edy Sutrisno (2011:

2) Budaya Organisasi merupakan suatu kekuatan sosial yang tidak tampak, yang dapat menggerakkan orang - orang dalam suatu organisasi untuk melakukan aktivitas kerja

Sistem makna bersama merupakan sekumpulan karakteristik yang dijunjung tinggi oleh organisasi. Menurut Danang Sunyoto (2012: 225) mengemukakan Karakteristik budaya organisasi adalah 1) inovasi dan keberanian mengambil resiko, 2) perhatian pada hal-hal rinci/detail, 3) orientasi hasil, 4) orientasi orang, 5) orientasi tim, 6) keagresifan atau aggressiveness, 7) stabilitas.

Proses terbentuknya organisasi yang dimulai dari tahap pembentukan ide dan diikuti oleh lahirnya sebuah organisasi. Meski pada tahap pembentukan ide organisasi belum menjadi realitas sosial dan belum berujud secara fisik tahap ini merupakan titik awal pembentukan budaya organisasi.

Menurut Achmad Sobirin (2007: 220) proses terbentuknya budaya organisasi adalah:

1. Para pendiri dan pimpinan lainnya membawa serta satu set asumsi dasar, nilai-nilai, perspektif, artefak ke dalam organisasi dan menanamkannya kepada para karyawan.

2. Budaya muncul ketika para anggota organisasi berinteraksi satu sama lain untuk memecahkan masalah-masalah pokok organisasi yakni masalah intergrasi internal dan adaptasi eksternal. 
3. Secara perorangan, masingmasing anggota organisasi boleh jadi menjadi seorang pencipta budaya baru (culture creator) dengan mengembangkan berbagai cara untuk menyelesaikan persoalanpersoalan individual seperti persoalan identitas diri, kontrol, dan pemenuhan kebutuhan serta bagaimana agar bisa diterima oleh lingkungan organisasi yang diajarkan kepada generasi penerus.

Sedangkan menurut Danang Sunyoto (2012: 226-227) proses penciptaan budaya organisasi terjadi melalui 3 cara yaitu:

1. Pendiri hanya merekrut dan mempertahankan karyawan yang memiliki satu pikiran dan satu perasaan dengan mereka.

2. Mereka melakukan indokrinasi dan mensosialisasikan cara piker serta berperilaku mereka kepada karyawan.

3. Perilaku pendiri sendiri bertindak sebagai model peran yang mendorong karyawan untuk mengidentifikasi diri menginternalisasikan

keyakinan, nilai, serta asumsi tersebut

Jadi adanya ide di dalam organisasi yang menanamkan nilainilai, keyakinan dan saling berinteraksi dan mengembangkan berbagai cara untuk menyelesaikan atau memecahkan masalah dengan memiliki satu pikiran dan satu perasaan dengan tujuan masalah dapat terselesaikan
Kinerja guru merupakan suatu hasil yang dicapai sesuai dengan tugas dan tanggung jawabnya baik secara kualitas maupun kuantitas yang dasarnya adalah persyaratan-persyaratan dan komunikasi terbuka antara kepala sekolah dengan guru atau sebaliknya, untuk mencapai tujuan atau rencana suatu organisasi

Menurut Wirawan (2009: 54) secara umum, dimensi kerja dapat dikelompokkan menjadi tiga jenis, yaitu 1) hasil kerja, 2) perilaku kerja, 3) sifat pribadi yang berhubungan dengan pekerjaan.

Faktor yang mempengaruhi kinerja menurut Setiawan dan Waridin (dalam Dipta Adi Prawatya dan Susilo, 2012: 2) faktor yang dapat mempengaruhi kinerja adalah disiplin kerja dan budaya organisasi.

Adapun penilaian kinerja Menurut Wilson Bangun (2012: 231) penilaian kinerja adalah proses yang dilakukan organisasi untuk mengevaluasi atau menilai keberhasilan karyawan dalam melaksanakan tugasnya.

Dari uraian di atas dapat disimpulkan bahwa penilaian atau evaluasi kinerja merupakan suatu alat untuk memperbaiki dan meningkatkan kinerja guna mencapai tujuan suatu organisasi atau perusahaan yang efektif dan efisien.

Kinerja guru juga berguna sebagai dasar dan alat untuk mengetahui sejauh mana guru dapat menyelesaikan pekerjaannya, untuk memotivasi guru, serta memperbaiki dan mengembangkan kecakapan guru. Sehingga dapat mempermudah dalam penempatan maupun balas jasa yang akan diberikan sesuai 
dengan prestasi yang telah mereka dapatkan.

Beberapa manfaat penilaian kinerja guru menurut Wibowo (2013: 10-11) Manajemen kinerja memberikan manfaat bukan hanya bagi organisasi, tetapi juga manajer dan individu.

Tujuan dari penelitian ini adalah mengetahui ada tidaknya pengaruh budaya organisasi terhadap kinerja guru di SMK Negeri 2 Ngawi Tahun 2014. Dalam penelitian ini terdapat satu variabel bebas yaitu budaya organisasi dan satu variabel terikat yaitu kinerja guru

\section{METODOLOGI PENELITIAN}

Tempat penelitian dilaksanakan di SMK Negeri 2 Ngawi Tahun 2014, Jl Supriyadi Km 3. Desain penelitian yang digunakan sesuai dengan tujuan penelitian yang akan dilakukan. Dalam penelitian ini menggunakan desain penelitian deskriptif. Menurut Husein Umar (2011: 34), desain deskriptif bertujuan untuk menguraikan sifat atau karakteristik dari suatu fenomena tertentu. Jadi dalam riset dengan desain ini jangan melakukan kesimpulan yang terlalu jauh atas data yang ada, karena tujuan dari desain ini hanya mengumpulkan fakta dan menguraikannya secara menyeluruh dan teliti sesuai dengan persoalan yang akan dipecahkan.

Penelitian ini dilakukan untuk mengetahui apakah budaya organisasi berpengaruh terhadap kinerja guru di SMK Negeri 2 Ngawi Tahun 2014. Menurut Sugiyono (2013: 61) variabel penelitian pada dasarnya adalah suatu atribut atau sifat atau nilai dari orang, obyek atau kegitan yang mempunyai variasi tertentu yang ditetapkan oleh peneliti untuk dipelajari dan kemudian ditarik kesimpulannya.

Menurut Husein Umar (2011:

48) variabel penelitian yang digunakan antara lain:

1. Variabel indenpenden yaitu variabel yang menjadi sebab terjadinya/terpengaruhnya variabel dependen.

2. Variabel dependen yaitu variabel yang nilainya dipengaruhi oleh variabel indenpenden.

Sedangkan menurut Sugiyono (2013: 61) variabel dalam penelitian dapat dibedakan menjadi:

1. Variabel bebas adalah merupakan variabel yang mempengaruhi atau yang menjadi sebab perubahannya atau timbulnya variabel dependen (terikat).

2. Variabel terikat merupakan variabel yang di pengaruhi atau yang menjadi akibat karena adanya variabel bebas.

Dalam penelitian ini yang menjadi Variabel bebas (X) adalah budaya organisasi. Variabel terikat (Y) dalam penelitian ini adalah kinerja guru.

Menurut Nanang Martono (2012: 74) populasi merupakan keseluruhan objek atau subjek yang berada pada suatu wilayah dan memenuhi syarat-syarat tertentu berkaitan dengan masalah dengan penelitian, atau keseluruhan unit atau individu dalam ruang lingkup yang akan diteliti.

Dari uraian di atas dapat disimpulkan, bahwa populasi merupakan keseluruhan obyek penelitian yang berada dalam tempat yang sama, serta telah dijadikan 
target penelitian untuk dipelajari dan menjadi hasil akhir dari suatu penelitian yang lengkap dan jelas.

Dalam penelitian ini yang menjadi populasinya adalah seluruh guru SMK Negeri 2 Ngawi Tahun 2014 yang seluruhnya berjumlah 40 orang. Berdasarkan pengertian tersebut maka sampel dalam penelitian ini adalah guru SMK Negeri 2 Ngawi Tahun 2014 sejumlah 40 guru.

Menurut Sugiyono (2013: 118-119), teknik sampling merupakan teknik pengambilan sampel.

Teknik pengambilan sampling yang akan digunakan dalam penelitian ini adalah teknik sampling jenuh. Menurut Sugiyono (2013: 124), sampling jenuh adalah teknik penentuan sampel bila semua anggota populasi digunakan sebagai sampel.

Dalam penelitian ini sumber data yang di gunakan adalah data primer. Menurut Husein Umar (2011: 42) Data primer merupakan data yang didapat dari sumber pertama baik dari individu atau perseorangan seperti seperti hasil dari wawancara atau hasil pengisian kuesioner yang biasa yang dilakukan oleh peneliti.

Pengambilan data primer dalam penelitian ini menggunakan suatu instrumen penelitian yang berupa angket atau kuesioner yang disebarkan kepada responden atau guru SMK Negeri 2 Ngawi Tahun 2014

Teknik pengumpulan data yang digunakan adalah kuesioner (angket). Menurut Sugiyono (2013: 199) kuesioner merupakan teknik pengumpulan data yang dilakukan dengan cara memberi seperangkat pertanyaan atau pertanyataan tertulis kepada responden untuk dijawabnya. Penggunaan angket dalam penelitian ini adalah mengambil data budaya organisasi dan kinerja guru di SMK Negeri 2 Ngawi Tahun 2014 dengan jumlah soal dalam kuesioner ini adalah 40 butir soal yang dibagi dalam 2 variabel, dengan perincian 20 soal budaya organisasi (X) dan 20 soal yang lain untuk variabel kinerja guru (Y).

Instrumen yang digunakan dalam penelitian ini adalah kuesioner yang merupakan teknik pengumpulan data melalui daftar pernyataan yang diajukan kepada responden. Sistem yang digunakan berupa pemberian skor berdasarkan skala Likert.

Menurut Sugiyono (2013: 134) skala Likert digunakan untuk mengukur sikap, pendapat dan persepsi seseorang atau sekelompok orang tentang fenomena sosial. Jawaban setiap item instrumen yang menggunakan skala Likert mempunyai gradiasi dari sangat positif, yang dapat berupa kata-kata antara lain sangat setuju, setuju, tidak setuju, sangat tidak setuju.

Sedangkan menurut Kinnear (dalam Husein Umar, 2011:70), skala Likert berhubungan dengan pernyataan tentang sikap seseorang terhadap sesuatu, misalnya setujutidak setuju, senang-tidak senang, dan baik-tidak baik.

\section{HASIL PENELITIAN \\ Variabel Budaya Organisasi}

Diskripsi dari Budaya

Oraganisasi dengan jumlah data $(\mathrm{N})$ sebanyak 40 orang memiliki deskripsi data sebagai berikut: (a) 
Jumlah skor total 2499; (b) Nilai rata-rata hitung (mean) sebesar 62,475; (c) Median sebesar 62,00; (d) Modus sebesar 58; (e) Standar Deviasi sebesar 7,811; (f) Nilai minimum sebesar 42; (g) Nilai maksimum sebesar 77 .

Dari hasil analisis deskriptif budaya organisasi dapat diketahui hasil analis kuisioner dari 40 guru yang berada di atas nilai rata-rata $\geq$ 62,475 sebanyak 21 guru atau $52,5 \%$. Sedangkan yang dibawah rata-rata sebanyak 19 guru atau 47,5\%. Hal ini dapat disimpulkan budaya organisasi di SMK Negeri 2 Ngawi Tahun 2014 adalah baik, karena 21 guru atau 52,5\% berada diatas rata-rata.

\section{Variabel Kinerja}

Diskripsi dari Kinerja Guru dengan jumlah data $(\mathrm{N})$ sebanyak 40 orang memiliki deskripsi data sebagai berikut: (a) Jumlah skor total 2528; (b) Nilai rata-rata hitung (mean) sebesar 63,20; (c) Median sebesar 61,50; (d) Modus sebesar 59; (e) Standar Deviasi sebesar 6.929; (f) Nilai minimum sebesar 47; (g) Nilai maksimum sebesar 75 .

Dari hasil analisis deskriptif kinerja guru diatas dapat diketahui hasil analis kuisioner dari 40 guru yang berada di atas nilai rata-rata $\geq$ 62,475 sebanyak 22 guru atau $55 \%$. Sedangkan yang dibawah rata-rata sebanyak 18 guru atau 45\%. Hal ini dapat disimpulkan di SMK Negeri 2 Ngawi Tahun 2014 adalah baik, karena 22 guru atau $55 \%$ berada diatas rata-rata.

\section{Hasil Uji Korelasi}

Hasil dari pengujian korelasi dapat diperoleh besarnya nilai $r_{\text {hitung }}$ adalah 0,834 dan $r_{\text {tabel }} 0,312$, dilain pihak besarnya $r_{\text {hitung }} \geq r_{\text {tabel }}(0,834 \geq$ $0,312)$ atau $\operatorname{Sig}_{\text {hitung }} \leq \operatorname{Sig}_{\text {prob }}(0,000 \leq$ $0,05)$. Selain itu diperoleh nilai $\mathrm{R}^{2}$ adalah 0,696 jadi sumbangan pengaruh budaya organisasi terhadap kinerja guru yaitu $69,6 \%$, dan $30,4 \%$ dipengaruhi oleh faktor lain. Atas dasar korelasi tersebut dapat disimpulkan tolak Ho, artinya ada hubungan antara Budaya Organisasi terhadap Kinerja Guru di SMK Negeri 2 Ngawi Tahun 2014.

\section{Uji Fisher}

Berdasarkan hasil secara manual di atas diketahui bahwa besarnya nilai $F_{\text {hitung }}$ adalah 87.024 dan $\mathrm{F}_{\text {tabel }} 4,098$, dilain pihak besarnya Sig hitung $_{0,000}$ dan Sig $_{\text {prob }}$ 0,05 hal ini berarti bahwa nilai $F_{\text {hitung }} \geq \mathrm{F}_{\text {tabel }}$ $(87.024 \geq 4,098)$ atau Sig $_{\text {hitung }} \leq$ $\operatorname{Sig}_{\text {prob }}(0,000 \leq 0,05)$. Atas dasar Uji Fisher tersebut dapat disimpulkan Ho ditolak, artinya ada pengaruh antara Budaya Organisasi terhadap Kinerja Guru di SMK Negeri 2 Ngawi Tahun 2014.

Dalam Uji Fisher selain dapat digunakan untuk mencari pengaruh, dapat juga digunakan untuk menguji linearitas. Karena $F_{\text {hitung adalah }}$ $87.024 \geq \mathrm{F}_{\text {tabel }} 4,098$, berarti ada hubungan yang linear antara budaya organisasi dan kinerja guru.

\section{Uji t}

Atas dasar hasil secara manual di atas dapat dibuat garis regresi sebagai berikut $\mathrm{Y}=16.968+$ $0,740 X$, artinya apabila budaya organisasi ditingkatkan satu kali akan terjadi kenaikan kinerja guru sebanyak $0,740 \%$, apabila faktor yang lainnya tetap. 
Berdasarkan hasil secara manual di atas diketahui bahwa besarnya nilai $t_{\text {hitung }}$ adalah 9.329 dan $t_{\text {tabel }} 1,685$, dilain pihak besarnya Sig $_{\text {hitung }}$ 0,000 dan Sig prob 0,05, hal ini berarti bahwa nilai $t_{\text {hitung }} \geq t_{\text {tabel }}$ $(9.329 \geq 1,685)$ atau $\operatorname{Sig}_{\text {hitung }} \leq$ $\operatorname{Sig}_{\text {prob }}(0,000 \leq 0,05)$. Atas dasar uji beda pengaruh tersebut dapat disimpulkan Ho ditolak, artinya ada beda pengaruh antara Budaya Organisasi terhadap Kinerja Guru di SMK Negeri 2 Ngawi Tahun 2014.

\section{Simpulan Hasil Analisis}

Atas dasar hasil pengujian hipotesis dapat diambil simpulan sebagai berikut:

\section{Simpulan Uji Korelasi}

Hasil dari pengujian korelasi dapat diperoleh besarnya nilai $r_{\text {hitung }}$ adalah 0,834 dan $r_{\text {tabel }} 0,312$, dilain pihak besarnya $r_{\text {hitung }} \geq r_{\text {tabel }}(0,834 \geq$ $0,312)$ atau $\operatorname{Sig}_{\text {hitung }} \leq \operatorname{Sig}_{\text {prob }}(0,000 \leq$ $0,05)$. Selain itu diperoleh nilai $\mathrm{R}^{2}$ adalah 0,696 jadi sumbangan pengaruh budaya organisasi terhadap kinerja guru yaitu $69,6 \%$, dan $30,4 \%$ dipengaruhi oleh faktor lain.

Atas dasar korelasi tersebut dapat disimpulkan tolak Ho, artinya ada hubungan antara Budaya Organisasi terhadap Kinerja Guru di SMK Negeri 2 Ngawi Tahun 2014.

\section{Simpulan Uji Fisher}

Hasil pengujian Fisher dengan uji manual dapat diperoleh besarnya nilai $F_{\text {hitung }}$ adalah 87,024 dan $\mathrm{F}_{\text {tabel }} 4,098$, dilain pihak besarnya Sig $_{\text {hitung }}$ 0,000 dan Sig prob 0,05 hal ini berarti bahwa nilai $F_{\text {hitung }} \geq F_{\text {tabel }}$ $(87,024 \geq 4,098)$ atau Sig $_{\text {hitung }} \leq$ $\operatorname{Sig}_{\text {prob }}(0,000 \leq 0,05)$.
Sesuai hipotesis yang diajukan dapat disimpulkan bahwa ada pengaruh antara Budaya Organisasi terhadap Kinerja Guru di SMK Negeri 2 Ngawi Tahun 2014.

\section{Simpulan Uji t}

Dari hasil perhitungan atau pengujian secara manual diperoleh garis regresi sebagai berikut $\mathrm{Y}=$ $16.968+0,740 \mathrm{X}$, artinya apabila budaya organisasi ditingkatkan satu kali akan terjadi kenaikan kinerja guru sebanyak $0,740 \%$, apabila faktor yang lainnya tetap.

Berdasarkan hasil secara manual di atas diketahui bahwa besarnya nilai $t_{\text {hitung }}$ adalah 9.329 dan $t_{\text {tabel }} 1,685$, dilain pihak besarnya $\mathrm{Sig}_{\text {hitung }}$ 0,000 dan $\mathrm{Sig}_{\text {prob }}$ 0,05, hal ini berarti bahwa nilai $t_{\text {hitung }} \geq t_{\text {tabel }}$ $(9.329 \geq 1,685)$ atau Sig $_{\text {hitung }} \leq$ $\operatorname{Sig}_{\text {prob }}(0,000 \leq 0,05)$. Atas dasar uji beda pengaruh tersebut dapat disimpulkan Ho ditolak, artinya ada beda pengaruh antara Budaya Organisasi terhadap Kinerja Guru di SMK Negeri 2 Ngawi Tahun 2014.

\section{Pembahasan Uji Korelasi}

Untuk uji korelasi diperoleh besarnya nilai $r_{\text {hitung }}$ adalah 0,834 dan $\mathrm{r}_{\text {tabel }} 0,312$, dilain pihak besarnya $r_{\text {hitung }} \geq r_{\text {tabel }}(0,834 \geq 0,312)$ atau Sig $_{\text {hitung }} \leq \operatorname{Sig}_{\text {prob }}(0,000 \leq 0,05)$. Dengan demikian Ho ditolak, artinya ada hubungan yang signifikan antara Budaya organisasi dan kinerja guru di SMK Negeri 2 Ngawi Tahun 2014.

Selain itu diperoleh nilai $\mathrm{R}^{2}$ adalah 0,696 Menunjukkan bahwa budaya organisasi mempengaruhi kinerja guru sebanyak 69,6\%, 
sedangkan 30,4\% dipengaruhi oleh faktor lain.

\section{Pembahasan Uji Fisher}

Berdasarkan Uji Fisher diperoleh nilai $F_{\text {hitung }}$ adalah 87,024 dan $\mathrm{F}_{\text {tabel }} 4,098$, dilain pihak besarnya Sig $_{\text {hitung }}$ 0,000 dan Sig prob $_{\text {0,05 hal ini }}$ berarti bahwa nilai $F_{\text {hitung }} \geq \mathrm{F}_{\text {tabel }}$ $(87,024 \geq 4,098)$ atau Sig $_{\text {hitung }} \leq$ $\operatorname{Sig}_{\text {prob }}(0,000 \leq 0,05)$.

Atas dasar Uji Fisher tersebut dapat disimpulkan Ho ditolak, artinya ada pengaruh antara Budaya Organisasi terhadap Kinerja Guru di SMK Negeri 2 Ngawi Tahun 2014.

\section{Pembahasan Uji t}

Dapat dilihat hasil persamaan garis regresi $Y=16,968+0,740 X$, artinya apabila budaya organisasi ditingkatkan satu kali akan terjadi kenaikan kinerja guru sebanyak $0,740 \%$, apabila faktor yang lainnya tetap.

Berdasarkan Uji $\mathrm{t}$ nilai $\mathrm{t}_{\text {hitung }}$ adalah 9,329 dan $t_{\text {tabel }} 1,685$, dilain pihak besarnya Sighitung 0,000 dan Sig $_{\text {prob }} 0,05$ hal ini berarti bahwa nilai $t_{\text {hitung }} \geq t_{\text {tabel }}(9,329 \geq 1,685)$ atau Sig $_{\text {hitung }} \leq \operatorname{Sig}_{\text {prob }}(0,000 \leq 0,05)$. Atas dasar korelasi tersebut dapat disimpulkan Ho ditolak, artinya ada beda pengaruh antara Budaya Organisasi terhadap Kinerja Guru di SMK Negeri 2 Ngawi Tahun 2014.

$\begin{gathered}\text { Dari hasil } \\ \text { bahwa }\end{gathered}$
menunjukkan $\begin{array}{r}\text { Budiaya } \\ \text { hubungan }\end{array}$
organisasi mempunyai
sekaligus pengaruh terhadap kinerja.
Apabila di SMK Negeri 2 Ngawi
menerapkan dan meningkatkan
budaya organisasi maka dapat
menciptakan kinerja guru yang baik.
Menurut Edy Sutrisno $(2011: 2)$

Budaya Organisasi merupakan suatu kekuatan sosial yang tidak tampak, yang dapat menggerakkan orang orang dalam suatu organisasi untuk melakukan aktivitas kerja. Dengan adanya budaya organisasi yang baik, guru akan bertanggung jawab pada pekerjaannya dan dapat terselesaikan secara efektif dan efisien.

Budaya organisasi yang baik mencerminkan besarnya rasa tanggung jawab seseorang terhadap tugas-tugas yang diberikan kepadanya. Hal ini mendorong gairah kerja, semangat kerja dan terwujudnya tujuan organisasi.

\section{PENUTUP}

\section{Simpulan}

Berdasarkan hasil analisis data dan pembahasan pada bab sebelumnya dapat disimpulkan sebagai berikut.

1. Budaya Organisasi yang dilaksanakan di SMK Negeri 2 Ngawi cukup efektif dan efisien. Hal ini dapat dilihat dari tingkat budaya organisasi yang cukup tinggi. Berdasarkan hasil analis statistik deskriptif yaitu dengan jumlah data $(\mathrm{N})$ sebanyak 40 orang memiliki deskripsi data sebagai berikut: (a) Jumlah skor total 2499; (b) Nilai rata-rata hitung (mean) sebesar 62,475; (c) Median sebesar 62,00; (d) Modus sebesar 58; (e) Standar Deviasi sebesar 7,811; (f) Nilai minimum sebesar 42; (g) Nilai maksimum sebesar 77. Dari hasil analisis deskriptif budaya organisasi diatas dapat diketahui hasil analis kuisioner daro 40 guru yang berada di atas nilai rata-rata $\geq 62,475$ sebanyak 21 guru atau 52,5\%. Sedangkan 
yang dibawah rata-rata sebanyak 19 guru atau 47,5\%. Hal ini dapat disimpulkan budaya organisasi di SMK Negeri 2 Ngawi Tahun 2014 adalah baik, karena 21 guru atau $52,5 \%$ berada diatas rata-rata.

2. Kinerja guru merupakan suatu hasil kerja baik secara kualitas maupun kuantitas dalam suatu organisasi atau perusahaan. Kinerja guru dipengaruhi oleh beberapa faktor salah satunya yaitu budaya organisasi. Dengan diterapkannya sikap budaya organisasi yang baik, kinerja guru juga berjalan dengan baik dan memperoleh hasil yang maksimal sesuai dengan rencara atau tujuan awal dari sekolah. Bedasarkan hasil analis statistik deskriptif yaitu dengan jumlah data (N) sebanyak 40 orang memiliki deskripsi data sebagai berikut: (a) Jumlah skor total 2528; (b) Nilai rata-rata hitung (mean) sebesar 63,20; (c) Median sebesar 61,50; (d) Modus sebesar 59; (e) Standar Deviasi sebesar 6.929; (f) Nilai minimum sebesar 47; (g) Nilai maksimum sebesar 75. Dari hasil analisis deskriptif kinerja guru diatas dapat diketahui hasil analis kuisioner daro 40 guru yang berada di atas nilai ratarata $\geq 62,475$ sebanyak 22 guru atau $55 \%$. Sedangkan yang dibawah rata-rata sebanyak 18 guru atau $45 \%$. Hal ini dapat disimpulkan di SMK Negeri 2 Ngawi Tahun 2014 adalah baik, karena 22 guru atau $55 \%$ berada diatas rata-rata.

3. Budaya Organisasi mempunyai pengaruh terhadap kinerja guru di SMK Negeri 2 Ngawi Tahun 2014. Terbukti dari hasil analisis regresi yang memuat uji korelasi, uji F dan uji t. Dari hasil korelasi diperoleh hasil nilai $r_{\text {hitung }} \geq r_{\text {tabel }}(0,834 \geq 0,312)$ atau $\operatorname{Sig}_{\text {hitung }} \leq \operatorname{Sig}_{\text {prob }}(0,000 \leq$ 0,05). Sedangkan nilai determinasi yang diperoleh nilai $\mathrm{R}^{2}$ (R Square) adalah 0,696. Jadi, sumbangan pengaruh Budaya organisasi terhadap kinerja sebesar $\quad 69,6 \% \quad$ sedangkan sisanya sebesar $30,4 \%$ dipengaruhi oleh faktor lain. Dari Hasil Uji $F$ nilai $F_{\text {hitung }} \geq$ $F_{\text {tabel }}(87,024 \geq 4,098)$ atau $\operatorname{Sig}_{\text {hitung }} \leq \operatorname{Sig}_{\text {prob }}(0,000 \leq 0,05)$. Dari Uji t diperoleh garis regresi yaitu $\mathrm{Y}=16,968+0,740 \mathrm{X}$, artinya apabila budaya organisasi ditingkatkan satu kali akan terjadi kenaikan kinerja guru sebanyak $0,740 \%$, apabila faktor yang lainnya tetap. Sedangkan, nilai $t_{\text {hitung }} \geq t_{\text {tabel }}$ $(9,329 \geq 1,685)$ atau Sig $_{\text {hitung }} \leq$ Sig $_{\text {prob }}(0,000 \leq 0,05)$. Jadi, berdasarkan uji korelasi, uji $\mathrm{F}$ dan uji t dapat disimpulkan ada pengaruh Budaya Organisasi Terhadap Kinerja Guru di SMK Negeri 2 Ngawi.

\section{Saran}

Sesuai dengan kesimpulan dari penelitian penulis lakukan di SMK Negeri 2 Ngawi Tahun 2014 maka penulis memberikan beberapa saran yang nantinya dapat bermanfaat untuk meningkatkan budaya organisasi dan kinerja guru. 


\section{Bagi Guru}

1. Diharapkan guru mampu meningkatkan budaya organisasi dalam bekerja. Sehingga dapat mencapai tujuan sekolah dan bertanggung jawab terhadap tugas yang telah diberikan.

2. Diharapkan guru ikut berorganisasi sebab berorganisasi akan membuka wawasan serta meningkatkan kualitas kinerja guru.

3. Diharapkan masing-masing guru menyusun pola pengembangan karier guru yang mampu menumbuhkan budaya organisasi yang kondusif sehingga dapat meningkatkan kinerja guru.

4. Diharapkan masing-masing guru menciptakan budaya organisasi untuk mempertahankan dan meningkatkan kinerja guru dimasa yang akan datang.

\section{Bagi Sekolah}

Diharapkan sekolah mengembangkan budaya berorganisasi karena budaya berorganisasi akan memajukan dan meningkatkan kualitas sekolah.

\section{DAFTAR PUSTAKA}

Abdul Aziz Wahab. 2011. Anatomi Organisasi dan Kepemimpinan Pendidikan Telaah Terhadap Organisasi Dan Pengeloaan Organisasi Pendidikan. Bandung: Alfabeta.

Achmad Sobirin. 2007. Budaya Organisasi Pengertian Makna Dan Aplikasinya
Dalam Kehidupan

Organisasi. Yogyakarta: UUP STIM YKPN.

Anwar Prabu Mangkunegara. 2010. Evaluasi Kinerja SDM. Bandung: Refika Aditama.

Anwar Prabu Mangkunegara. 2013. Manajemen Sumber Daya Manusia Perusahaan. Bandung: Remaja Rosdakarya.

Danang Sunyoto. 2012. Manajemen Sumber Daya Manusia Dilengkapi Dengan Budaya Oranisasi Pengembangan Organisasi Outsourcing. Yogyakarta: CAPS.

Dipta Adi Prawatya dan Susilo Toto Raharjo dengan alamat: http://ejournals1.undip.ac.id/index.php/djo m.

Edy Sutisno. 2011. Budaya Organisasi. Jakarta: Kencana Predana Media Group.

Gabriel Amin Silalahi. 2003. Metodologi Penelitian dan Studi Kasus. Sidoarjo: CV Citra Media.

Husaini Usman dan Purnomo Setiady Akbar. 2011. Metodologi Penelitian Sosial. Jakarta: Bumi Aksara.

Husein Umar. 2011. Metode Penelitian untuk Skripsi dan Tesis Bisnis. Jakarta: Raja Grafindo Persada. 
Juliansyah Noor. 2013. Metodologi Penelitian Sripsi Tesis Disertasi Dan Karya Ilmiah. Jakarta: Kencana.

Khaerul Umam. 2012. Manajemen Organisasi. Bandung: Pustaka Setia.

Lijan Poltak Sinambela. 2012. Kinerja Pegawai Teori Pengukuran dan Implikasi. Yogyakarta: Graha Ilmu.

Moeheriono. 2009. Pengukuran Kinerja Berbasis Kompetensi Competency Based Human Resource Management. Jakarta: Ghalia Indonesia.

Nanang Martono. 2012. Metode Penelitian Kuantitatif Analisis Isi dan Analisis Data Sekunder. Jakarta: PT RajaGrafindo Persada.

Sugiyono. 2013. Metode Penelitian Pendidikan (Pendekatan Kuantitatif, Kualitatif dan $R \& D)$. Bandung: Alfabeta.

Suharsimi Arikunto. 2013. Prosedur Penelitian Suatu Pendekatan Praktik. Jakarta: Rineka Cipta.

Sukardi. 2013. Metodologi Penelitian Pendidikan Kompetensi dan Praktiknya. Jakarta: Bumi Aksara.

Surya Dharma. 2012. Manajemen Kinerja Falsafah Teori Dan Penerapannya. Yogyakarta: Pusataka Pelajar.
Taliziduhu Ndraha. 2010. Budaya Organisasi. Jakarta: Rineka Cipta.

Taliziduhu Ndraha. 2005. Teori Budaya Organisasi. Jakarta: Rineka Cipta.

Tutik Rachmawati dan Daryanto. Penilaian Kinerja Profesi Guru Dan Angka Kreditnya. Yogyakarta: Gava Media.

Usman Rianse dan Abdi. 2012. Metode Penelitian Sosial Ekonomi Teori Dan Aplikasi. Bandung: Alfabeta.

Veithzal Rivai dan Ella Jauvani Sagala. 2013. Manajemen Sumber Daya Manusia untuk Perusahaan. Jakarta: Raja Grafindo Persada.

Wibowo. 2013. Manajemen Kinerja. Jakarta: Raja Grafindo Persada.

Wilson Bangun. 2012. Manajemen Sumber Daya Manusia. Jakarta: Erlangga.

Wirawan. 2009. Evaluasi Kinerja Sumber Daya Manusia. Jakarta: Salemba Empat. 